\title{
Formation of Smarter Government services in Egypt
}

\author{
Christina Albert Rayed Assad
}

\begin{abstract}
The revolution to smart government is being taking in many developing countries. Governments are transforming themselves into smart governments in order to respond to the needs of its citizens. By developing an integrated electronic logistic infrastructure, the governments can use Information and communication technology (ICT) tools to transport to the smart government services. By using smart government services, which can inform and assist citizens and can reduce the investments in building, materials and staff in various departments. The objective of this paper is spotting on the formation to smarter government services in Egypt. The proposed conceptual model for the phases of transformation to smarter government services will help the citizens to participate and communicate with the government in decisions making and the future of predictive government by using business intelligent. The purpose of this is to formation of smart government by using the new technologies like GIS (Geographical Information System), GPS (Global Positioning System) and RS (Remote Sensing) in order to improve governance processes and outcomes these will impact on the delivery of public services to citizens.
\end{abstract}

Index Terms - Smart government, Developing countries, Information and communication technology (ICT), GIS (Geographical Information System).

\section{INTRODUCTION}

Utilization of majority of the data through the using of Information and Communication Technology (ICT) for governments can empower the mix between the primary pillars to update and enhance its services, rapidly reach to the citizens connect citizens and build interactions between stakeholders by bringing rapid and radical changes in the whole process in order to Simple, Moral, Accountable, Responsive and Transparent (SMART) governance. GIS provides spatial analysis, spatial planning and spatial decision making system by presenting the results in maps. The smarter government can use the remote sensing, photogrammetry, geographical information system (GIS), digital cartography and GPS to solve many organizational and developmental problems.

By increasing the technology-based solutions lead to transform to intelligent urban development, or smarter infrastructures, to reach to sustainable development in developing countries. On the other hand there is a big role of citizens in these countries to start this transformation to smarter government and cities.

Smart government aims to facile the relation between government and other stakeholders through the interaction between government and citizens (G2C), government and business enterprises (G2B ), and inter-agency relationships (G2G) more friendly, convenient, transparent, and inexpensive.

These services have shown remarkable results in management of some areas such as waste, mobility, human resource, etc. These platforms are still evolving and being created and developed after a thorough research, planning and consultative process with various stakeholders [1].

In the face of political and economic issues around the globe, a need arises to redefine the balance between the governing parties and their constituents, in a citizencentered paradigm that will bring the human factor back into the centre of the equation and will focus on the citizens and their well-being [2].

E-government can be viewed as the administration, rules, regulations and frameworks organized by a government for service delivery as well as to communicate, co-ordinate and integrate processes within itself. The term e-government can include three perspectives government and citizen (G2C), government and businesses (G2B), and between government agencies (G2G). Therefore, the smarter government in developing countries must use the new technologies tools in these three perspectives. UAE, Bahrain and Saudi Arabia are considered to be leading the Arab countries in the delivery of online public services.

There are many studies of applying e-government in developing countries. As A. T. Chatfield and O. Alhujran presented a comparative analysis of some Arab developing countries that apply the e-Government services. This study demonstrated that Egypt's e-Government portal provides one-way information flows, two-way interaction and Edemocracy, while Algeria, Morocco and Tunisia only provide one-way information flows. To provide two-way interaction service delivery, online identification and authentication is required [3].

In addition to, UAE and Bahrain in particular are setting examples in taking a Whole-Government and peoplecentered development approach [4].

\section{THE ELEMENTS OF SMARTER GOVERNMENT}

There are four main elements to transform to the smarter government as shown in figure 2. First element is people who contain all the workers in the government in order to build a sustainable development of smarter government. Also, the participation of citizens is very important issue to success the smarter government. The participation, intention and trusting of citizens is very important issue to success the applying of smarter government in developing countries. The team of applying the smarter government must be professionals and warring of the society, culture and moral issues.

Published on May 18, 2019.

Christina Albert Rayed Assad is with the Computer and Information System Department, Sadat Academy for Management Science, Cairo, Egypt (sams.christina.albert@gmail.com). 


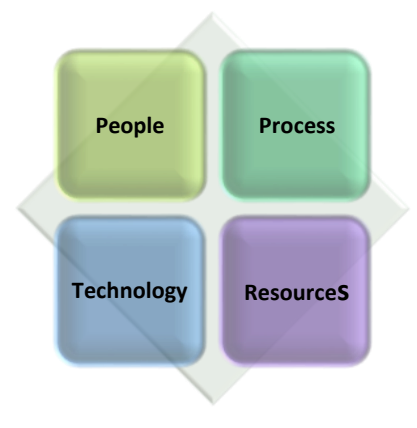

Fig. 1. Elements of smarter government

The second element includes computer and communication technologies. These technologies present opportunities to the government to direct to innovation and smart aspects. Smart phones increase the using of the online services through the internet in developing countries. Smarter government can take the advantage of using Information Communication Technologies to reach a large number of citizens through different online service deliveries and options by using smart phones and mobile devices. The benefit of the new technology is increasing the rapid and effective of services that present to citizens and businesses.

The third element is that the practicality of a technical solution and the availability of technical resources and expertise. By identifying the resources required to complete the smarter government.

The last element contains the processes and steps that will be used to build and construct the smarter government as shown in figure 2. These processes include scoping, planning, staffing, analyzing, designing, organizing, directing, implementation and controlling the development of an acceptable smart government. The processes of applying smarter government are as following:

1) Scoping by setting the mission, vision and objectives.

2) Planning by identifying the tasks required to transform to smarter government.

3) Estimating by identifying the resources required.

4) Staffing by identifying the staff required.

5) Organizing by arranging the tasks and the roles of participants.

6) Monitoring by monitoring the whole tasks.

7) Assessing by measuring the success and failure factors.

8) Development by using sustainable developments of the public services.

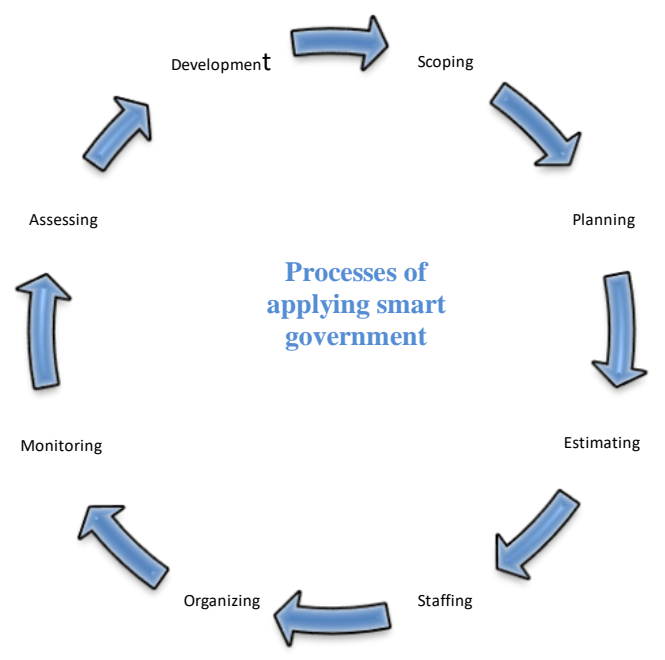

Fig. 2. Processes of applying smart government

\section{E-GOVERNMENT IN EGYPT}

Egypt has many characteristics of developing countries specially North Africa Countries like citizen's skills and behaviors, habits, social aspects cultures. Also Egypt has a high population rate and different demographic and social data.

Egypt needs for greater cooperation among the main governance stakeholders in order to strengthen the national integrity system (NIS) as a means of facilitating good governance. As long as the relationships among political parties, as well as between the state and civil society, remain adversarial, and public watchdog agencies remain largely disempowered, meaningful collaboration is unlikely to materialize [5].

The government should be able to offer the public services to the individuals and businesses in effective ways by using the new third platform technologies in order to achieve the needs and expectations of citizens. It is vital to scope on the participation of all the citizens in the new generation of e-government by using cloud computing, big data analytics, mobile computing, social networks and spatial data and analysis through the using of geographic information system and remote sensing.

Since 2004, The NCITP has paved the road for launching the Egyptian Information Society Initiative (EISI). These mechanisms are E-Readiness, E-health, Eculture, E-government, E-learning, The government of Egypt inaugurated e-government portal (www.egypt.gov.eg) in January 2004. Some services were placed in the portal to pilot test the project such as telephone e-billing, birth certificate, issuing, etc [6].

The top five African countries in terms of the number of features available on their e-Government websites are South Africa (460), Algeria (189), Egypt (161), Kenya (140), and Morocco (131). The top five countries in terms of mean number of online executable services are Egypt (2.28), South Africa (1.92), Tunisia (1.27), Morocco (1.05), and Mauritius (0.88), while the order (from first to last) in terms of the absolute number of online executable services is South Africa (144), Egypt (57), Morocco (22), Tunisia (19), and Mauritius (15). The top five ranked countries in Africa with respect to e-Government services in 2008 were Togo, Tunisia, Egypt, Eritrea, and Mauritius [7]. 


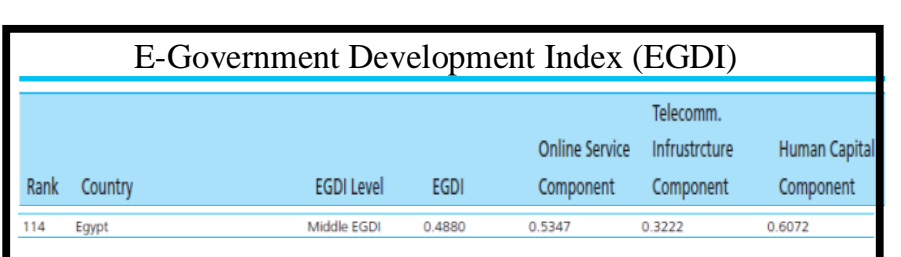

E-Government Development Index (EGDI) by region AFRICA

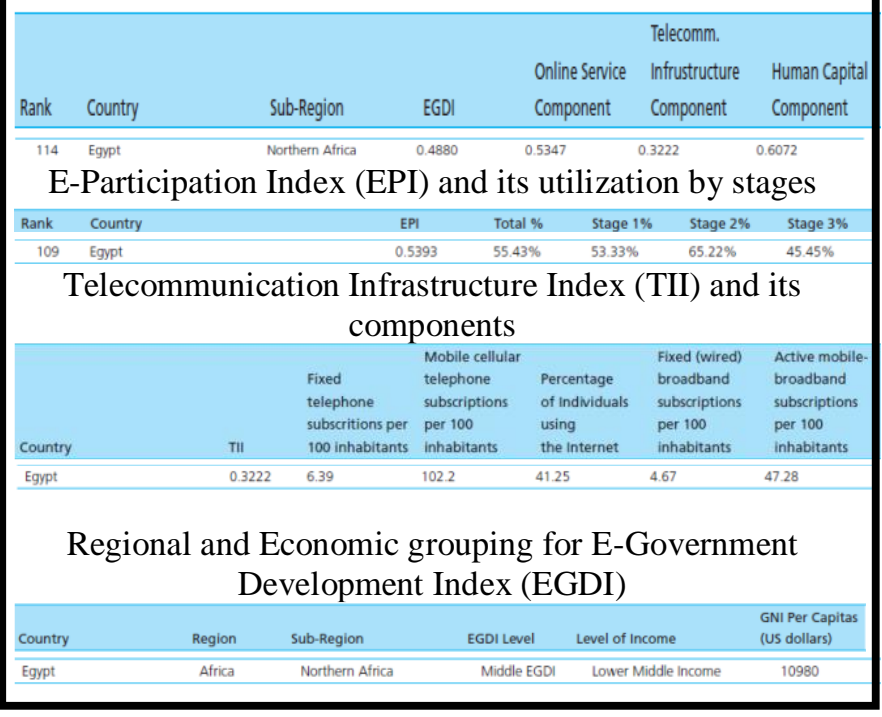

Fig. 3. E-government in Egypt

Sources: UNESCO Institute of Statistics http://data.uis.unesco.org/ http://hdr.undp.org/en/data

Egypt has also joined a number of international initiatives and projects to combat corruption. They include the MENA-OECD Task Force on Anti-Bribery, the OECD Good Governance for Development in Arab Countries Initiative, the Arab Anti-Corruption and Integrity Network (ACINET), and the UNDP-POGAR project to support the Ministry of Investment in the fight against corruption. Egypt is also a signatory to the UN Convention against corruption [8].

The Egyptian Local Government Development Program (ELGDP) is a component of the e-government Services program within the e-government Initiative, this program depends on the enhancement of citizens' services and the transformation to Smart Citizen-Service-Centers. Also, ELGDP doesn't mean the automation of services but also the reducing of time and enhancing the services [9].

\section{APPLYING SMARTER -GOVERNMENT IN EGYPT}

The objective of the Egyptian government is to push those efficiency, Quality, more transparency to gain Benefits through those conveyance for regionally. Coordinated smarter government requisitions is to take advantage for G2C, G2G and G2B services, remote infrastructure services as well as business process outsourcing services, governments have been investing on multiple core business applications for various services over the last couple of years.

The government should be able to offer the public services to the individuals and businesses in effective ways by using the new third platform technologies in order to achieve the needs and expectations of citizens. It is vital to scope on the participation of all the citizens in the new generation of e-government by using cloud computing, big data analytics, mobile computing, social networks and spatial data and analysis through the using of geographic information system and remote sensing towards smarter government.

Smarter government offers various chances on. Resolve a few managerial issues. In practical, challenges confronting a significant number African countries like Egypt. Smarter government can obtain a Change possibility in the accompanying areas like public services and citizens participation.

Also, there are processes that can be included in the smarter government such as helping in preparing statistics for all sectors in the state. These sectors are including public administration, economic activities, medical statistics, employment and labor data. Egypt like most African countries, data is hardly available in high quality, up to date and consistency. Using third platform technologies and new information technologies, is very helpful to automate data and generate online statistical reports. According to UNDESA, the e-government development index of Africa ( excluding South Africa) is the lowest among the five regions of the world [10].

Applying smarter government in Egypt will depend on two ways the first one is presenting the services to citizens and the second way is presenting the services to businesses. For the services that can be present to citizens like national identification card, birth and death certificates, electricity, water, and gas bills, car license, transportation tickets reservation, and so on. And the services related to businesses can include steps of opening a new factory, business manuals for different types of industries, commercial license, banking services, online payment for taxes, and customer services [11].

By applying smart government in Egypt, there is a need to build a public trust for the Egyptian Society in order to gain the outcomes of smart government. The role of local authorities in sustainable development is essential to reach to the whole categories of citizens.

An increase in citizens' expectations for effective, equitable and citizen-centric services, demands a shift from inward, disjointed and process-oriented organizational structures to highly collaborative frameworks for seamless delivery of services and enhanced development impact. Therefore, there are many benefits of transformation to citizen centric are transparency and accountability, efficiency, better service to citizens, business and industry.

\section{CONCEPTUAL MODEL FOR THE TRANSFORMATION TO SMARTER GOVERNMENT SERVICES IN EGYPT}

Advanced change doesn't rely main for innovations alone, but the change must include many factors that offer accessible, fast, and dependable on citizens' benefits. Adapting smart government will backing change towards economical, social, Policies, administrations, rules, regulations, and huge numbers for these instruments would delay the applying of smart cities.

This proposed conceptual model of transformation to smarter government services includes of three main pillars smarter government fields, smarter government functions and smarter government tools as shown in figure 4. This 
conceptual model can enhance in applying smarter government in developing countries specially Egypt. So the conceptual model can use as a guide for these countries.

From the first pillar, There are many sectors can be benefited from the using of smarter government such as transportation, health, energy, water, sewers, safety and security and urban construction and planning special for the new cities. By applying the smarter government will lead to reduce costs and consumption for many critical resources, increase and enhance the citizens' services, enhance the performance of the government.

Next the second pillar which includes many functions of smarter government like asset management of local governorates, emergency response, develop efficient work flow for all the ministries and sectors in the government, site selection for all vital entities such as schools, health centers, universities, roads,......etc, and the main fundamental function is public services, these services contain services for citizens and businesses.

The last pillar is the tools that can assist for applying smarter government. Some of these tools include Artificial Intelligence, social media, space technology applications and geospatial data [12]. Technological advancements create new capabilities for communication and are used as tools to gain and share information and to learn the skills needed to participate in a globalized economy [13].

Using the new technologies will enhance the functions of smarter government in the second pillar which improve data availability and analytics systems towards the achievement of sustainable development. Matt Alderton said that the benefit of using GIS is increased because of the challenges like budget constraints, stakeholder resistance and data silos. As Chris Thomas the director of government markets for GIS software demonstrated that GIS changes the dynamics of cost savings, efficiencies, productivities and public engagement by applying it in the smart government. In addition to these benefits, GIS is a magical stick to build spatial database and spatial decision support system in real time [14].

Using geographic information system (GIS) GIS can be utilized in many fields such as safety and security, urban construction and development, planning new cities, disaster recovery, assessment, mitigation of damage, diseases surveillances and occurrences, educational services and so on. By using geo-referenced and spatial analysis, the ministries can take an intelligent decisions based on intelligent spatial decision support system. Another very vital tool is the using of remote sensing and satellite imagery and communications for collecting and analyzing satellite data that could be supported through integration and cooperation all over the world.

Also, mobile and web applications must invoke in the applying of smarter government. There is a need to offer more than one mobile applications that can facilitate and assist the multiple services to citizens. There mobile applications can be implemented for different fields such as health, education, labor.......etc.

In addition to the previous technologies, the government must invoke others third platform technologies such as artificial intelligence, cloud computing, big data \& analytics, mobile computing, social networks and machine-learning can improve the level social and public services in a Egypt, including e-banking, e-commerce, e-health, e-learning and so on . Artificial intelligence will enhance the efficiency and effectiveness of public services and also will be using in prediction of some disasters and solving many problems.

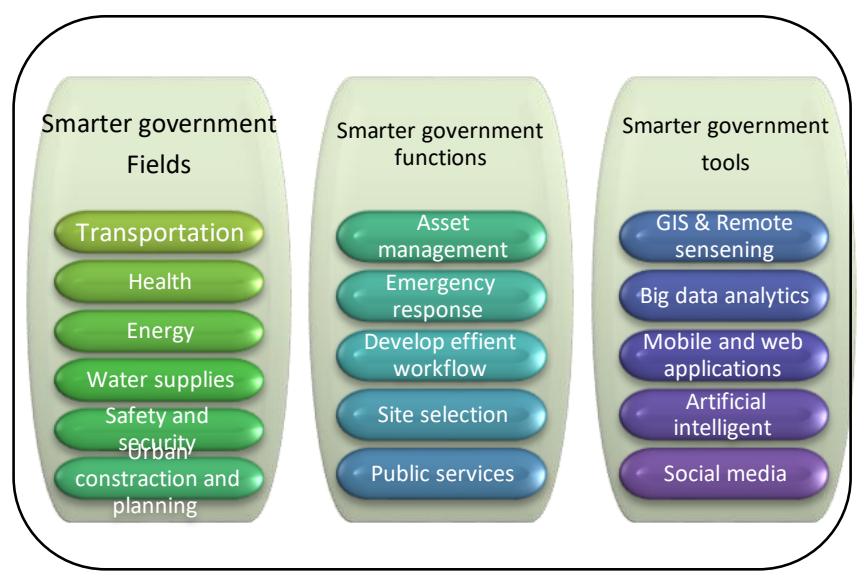

Fig. 4. Conceptual model for the transformation to smarter government services in Egypt

\section{THE CHALLENGES OF THE FORMATION OF SMARTER GOVERNMENT IN EGYPT}

In recent times, many developing countries have gained much attention within the government in particular and the public sector in general, by providing collaborative and comprehensive ICT designing, planning as well as managing processes for e-Government transformations so as to enable a sustainable connected whole-of government model.

There are many challenges that face the developing countries like budget constraints, stakeholder resistance and data silos, the GIS and remote sensing can be used with some limitations of unavailability and inefficiency of reliable data.

When transformation to smarter government, study the physical, social, cultural and economic issues in the developing countries is very important. Also, the developing countries can face with the lack of capital and skilled human resource for applying the new technology of GIS, GPS and Remote Sensing.

Not only developed countries but also many developing countries, are applying online services to their citizens. Towards to smarter government require protection of services and the confidential information of citizens against such as financial loss, abuse incidents and unavailability of services. So that, security issues include (CIA) Confidentiality, Integrity and Availability have to be taken and implemented when introducing smart government to ensure the protection of applying services and confidential information of the citizens.

The planning of smart government depends on many factors such as organizational, soci-economics, political, finical, top management support and commitment, infrastructure (technical resources and human skills).so that, it is important to understanding and analyzing social culture, economics , financial and political issues in Egypt, besides the understanding of behaviors and ability of Egyptian citizens to implement the smarter government.

The smart government needs to use modern tools and techniques of Remote Sensing (RS), Geographical Information System (GIS), Global Positioning System 
(GPS). But, there is a lack in geo-databases and accuracy of databases for the citizens and the urban services in developing countries in addition to the shortage of skilled human resource that will operate these new technologies.

As Elaswad et al analyze some of the Egyptian online services, using the CORAS risk analysis tool, this study defined some critical problems that may thread the personal information, escalated privileges and unauthorized access. Some of these problems divided into two parts the first part related to citizens related to limited skills and abilities and the second part related to poor management of services [15].

Laila El Baradei et al mentioned that the main problem for applying smarter government in Egypt is marketing aspects. There are lower expected numbers of citizens using e-government services despite of the increasing of using internet in Egypt in all governorates and the government efforts to present its services online in more easy way [16].

From the previous studies there are many challenges of transformation to smarter government like socio-economic factors, legal and political factors, institutional and organizational infrastructure factors, cultural factors, security and protection issues, trust, ability and skills of citizens, and also marketing aspects to smart government as seen in figure 5 . These challenges should be taken in account when transforming to smarter government and also there are many issues related to citizens must be considered such as trust, ease of use, money, ability, skills, financial security, time, and services quality. All these factors are very important to success the citizens' intentions and trust in using smarter government services.

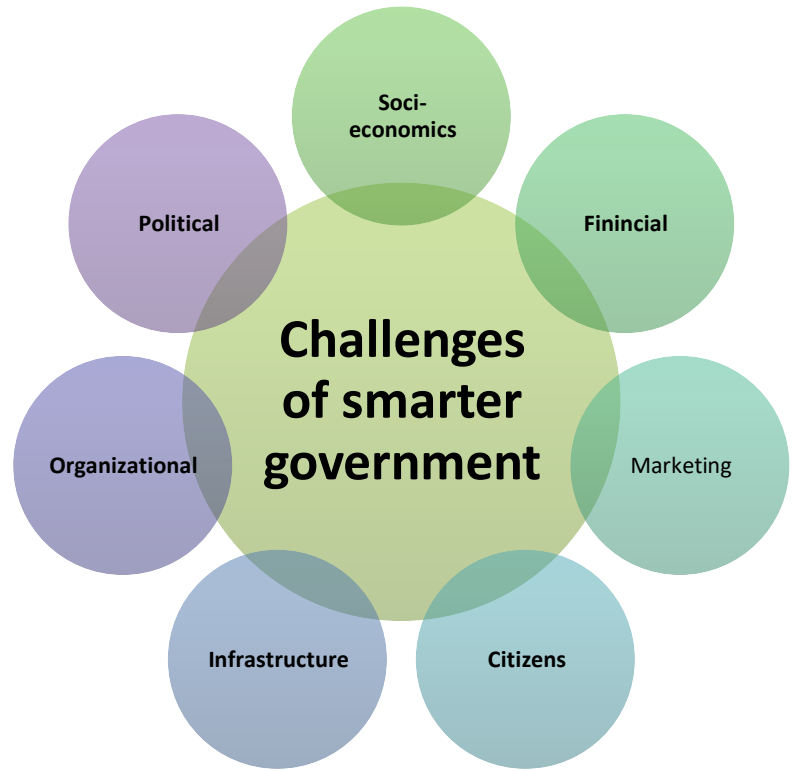

Fig. 4. Challenges of the formation of smarter government in Egypt

\section{IMPACTS OF SMARTER GOVERNMENT SERVICES IN EGYPT}

By applying the proposed conceptual model for the transformation to smarter government in Egypt, there are many positive impacts of smarter government as following:

1) Increase knowledge which enhance in problem solving and taking decisions in the right time.

2) Enhanced correspondence for people in general.
3) Comprehensive perspective for programs, plans and results for the current and predict for the future.

4) Dealing with and decreasing hazards and risks.

5) Moving forward operational effectiveness.

6) Maximizing transparency and responsibility.

7) Expanded accountability; expanded viability and effectiveness.

8) Cooperating between all stakeholders

9) Short and long strategic planning that helps in decision making.

\section{CONCLUSION}

According to the rapid and continues development of technologies and new trends can lead to the smart, intelligent, participatory and mobile government. The government can solve range of urban problems that Egypt is facing including high population, living conditions, and lack of resources, economic issues, some bureaucracy issues.

The importance of transform to smarter government services is arising in the recent years. The smarter government will improve the quality of public services for all the citizens in Egypt. By Appling the proposed conceptual model for the transformation to smarter government, It is possible to establish mobile, sustainable, smart, participatory, and modern government in Egypt. The smart government will present Disaster management solutions, mobile applications and web sites, portals for businesses, Participatory government, GIS maps and spatial database, integration between all ministries, insights and knowledge for the future to facilitate the public services.

The smart government will raise the quality of public management and, consequently, of the municipality and the living conditions of the population. can effectively improve the quality of life of the population.

\section{RECOMMENDATIONS}

Formation of smarter government in Egypt will built worldwide economy and administrations that are required to make decisions and solve problems in the right time. So that, there are many issues that will enhance the role of smarter government as following:

1) Creating a national e-strategy by using new mobile technologies.

2) Endeavor inventive activities that aggravate a difference in the relationship between citizens and government.

3) Reforming legislature methods coating regions for example, revenues, expenditures,. Procurement, administration delivery, citizen interaction and so on.

4) Saving and analyzing data to get information, in a huge amount of data get knowledge which pushing preparation for national through using internet and electronic media.

5) Increasing the necessity of protecting citizen rights, properties, privacy and the moral and society rights in Egypt.

6) Creating a general strategy to apply the smarter government as stages on the different services that the government can present through the smarter government. 


\section{REFERENCES}

[1] Satyendra Singh, E-Governance State-of-the-Art Survey: Stuttgart, Germany, Springer Science+Business Media Singapore 2015 T.M. Vinod Kumar (ed.), E-Governance for Smart Cities, Advances in 21st Century Human Settlements, DOI 10.1007/978-981-287-287-6_2, 2015.

[2] Rahav, Rahav, A., Citizen Centricity. Icentred blog. [Online] Available: http://www.icentered.com/citizen-centricity, September 1, 2012.

[3] A. T. Chatfield and O. Alhujran, "A cross-country comparative analysis of e-government service delivery among Arab countries," Inf. Technol. Dev., vol. 15, no. 3, pp. 151-170, 2009.

[4] Ali M. Al-Khouri, e-Government in Arab Countries: A 6-Staged Roadmap to Develop the Public Sector, Journal of Management and Strategy, Vol. 4, No. 1; 2013.

[5] Transparency International Report, The good governance challenge: Egypt, Lebanon, Morocco and Palestine, www.transparency.org, 2010.

[6] Azab, N., Ali, M. and Dafoulas, G."Incorporating CRM in EGovernment: Case of Egypt", LADIS International Conference eCommerce, 2006.

[7] Abebe Rorissa, Dawit Demissie, An analysis of African eGovernment service websites, Published by Elsevier Inc, www.elsevier.com/locate/govinf., doi:10.1016/j.giq.2009.

[8] United Nations Convention Against Corruption (UNCAC, 2003), Available: www.un.org/media/2003 , 2003.

[9] Abdelsalam H, ElKadi H, Gamal S. Egypt local government websites maturity: current status. E-infrastructures and e-services for developing countries. Springer; 2011.

[10] UNDESA (n.d). Technical Cooperation Projects on E- government . Available

http://unpan1.un.org/intradoc/groups/public/documents/un/unpan0250 99.pdf, 2012.

[11] F. H. Sayed, "Innovation in Public Administration: The Case of Egypt," Europe, no. April, 2004.

[12] GSMA, Regulatory and policy trends impacting Digital Identity and the role of mobile: Considerations for emerging markets.[online] Available at: https://www.gsma.com/mobilefordevelopment/wpcontent/uploads/2016/10/Regulatory-and-policy-trendsimpactingDigital-Identity-and-the-role-of-mobile.pdf,2016 .

[13] Warschauer, M., The Digital Divide and Social Inclusion. [online] Americas Quarterly. Available at: http://www.americasquarterly.org/warschauer, 2012.

[14] Matt Alderton, 8 steps to smarter government GIS,GCN, The Technology that Drives Government IT, Mar 07, 2016

[15] Elaswad, Othoman; Jensen, Christian D., Introducing E-Government in Developing Countries Analysis of Egyptian e- Government Services, IST-Africa 2016 Conference Proceedings Link to article, DOI: 10.1109/ISTAFRICA.2016.7530669, 2016.

[16] Laila El Baradei, Hamed M. Shamma, Noha Saada,, Examining the marketing of e-Government services in Egypt, International Journal of Business and Public Management (ISSN: 2223-6244) Vol. 2(2): 1222, Available online at: http//:www.journals.mku.ac.ke, April 2012.

\section{BIOGRAPHIES OF AUTHOR}

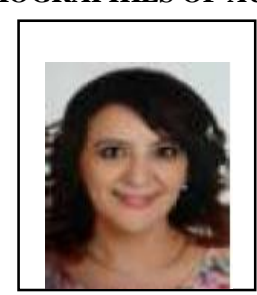

Christina Albert Rayed Assad

Associate Professor, Computer and Information

System Department, Sadat Academy for

Management Science, Cairo, Egypt. 